\title{
PENGARUH PEMBERIAN AIR KELAPA TERHADAP \\ PERTUMBUHAN DAN HASIL TANAMAN \\ KANGKUNG DARAT \\ (Ipomoea reptans)
}

\author{
Benyamin Edo dan Murdaningsih \\ Dosen Program Studi Agroteknologi Fakultas Pertanian Universitas Flores \\ J1. Sam Ratulangi-Paupire, Ende-Flores, NTT \\ murdaningsih11@gmail.com
}

\begin{abstract}
This study aims to determine the effect of doses of coconut water on the growth and yield of land water spinach.

The use of doses of coconut water as a treatment tested consists of $\mathrm{K} 0=\mathrm{Control}$; $\mathrm{K} 1=56.68$ liters $/ \mathrm{ha} ; \mathrm{K} 2=113.37$ liters $/ \mathrm{ha} ; \mathrm{K} 3=170.05$ liters $/ \mathrm{ha} ; \mathrm{K} 4=226.74$ liters / ha

The results of the study addressed the use of 226.74 liters / ha of coconut water doses which had a very significant effect on all observation variables. Where an increase in the dose of coconut water affects the increase in the average percentage of plant height of $5.27 \%$, the number of leaves is $4.58 \%$, the fresh weight of ground water spinach per plant is $0.26 \%$ and the weight of land spinach per hectare is $0.26 \%$
\end{abstract}

Keywords: Coconut Water, Land Water Spinach Plant

\section{PENDAHULUAN}

Kangkung darat (Ipomoea reptans) merupakan sayuran yang bernilai ekonomi dan persebarannya meluas cukup pesat di daerah Asia Tenggara.Tanaman kangkung darat sudah sangat dikenal di masyarakat Indonesia karena tanaman ini termasuk dalam sayuran daun yang dikonsumsi sehari-hari oleh masyarakat kita. Kandungan vitamin dan mineral yang terdapat pada kangkung terdiri dari 89,7 gram air, 3,0 gram lemak, 5,4 gram karbonhidrat, $29 \mathrm{mg}$ kalori, $73 \mathrm{mg}$ kalsium. 50 potassium, $32 \mathrm{mg}$ vitamin C, 0,07 mg vitamin B (Harjadi dan Suketi, 1999).
Produktivitas kangkung darat di Indonesia mencapai $50.000-60.000 \mathrm{~kg}$ per hektar (Harjadi dan Suketi, 1999). Namun di Kabupaten Ende produksi kangkung darat belum terdaftar di BPS Kabupaten Ende. Karena tanaman kangkung darat hanya ditanam dilahan pekarangan dan sebagian kecil yang ditanam secara intensif dilahan kering, sehingga optimalisasi produksi kangkung masih kurang.Dari aspek sosial dan ekonomi, tanaman kangkung darat memiliki prospek yang cukup baik jika dikembangkan ke arah agribisnis.Kangkung darat menempati urutan ke-14 dari 18 jenis sayur di Indonesia (Sawasemariai, 2012). 
Permasalahan rendahnya produksi kangkung juga disebabkan oleh belum digunakan inovasi teknologi murah dan tepat. Inovasi teknologi murah dan tepat yang dimaksud adalah dengan cara memanfaatkan sumber daya alam yang ada disekitar tanpa harus mengeluarkan biaya yang besar namun dapat memberikan hasil produksi yang tinggi. Pemanfaatan sumber daya alam yang sudah ada tersebut nantinya dapat dibuat menjadi bahan atau produk yang dapat diaplikasikan pada tanaman tanpa merusak lingkungan dan aman bagi konsumen.

Upaya peningkatan produksi kangkung dapat dilakukan dengan berbagai cara salah satunya adalah dengan penggunaan air kelapa.Penggunaan air kelapa dari hasil pertanian merupakan salah satu terobosan inovasi teknologi yang tepat dan murah, yang dapat digunakan atau dimanfaatkan untuk meningkatkan produksi tanaman karena mengandung unsur hara makro dan mikro tinggi sebagai hasil senyawa organik tumbuhan yang mengandung sel-sel hidup aktif dan aman terhadap lingkungan serta pemakaiannya.Pemanfaatan air kelapa merupakan salah satu alternatif teknologi yang tepat untuk meningkatkan produksi pada tanaman kangkung.Di kabupaten Ende sendiri air kelapa belum banyak dimanfaatkan secara baik oleh masyarakat pada umumnya.

Air kelapa banyak mengandung nutrisi yang dibutuhkan oleh tanaman sehingga mampu meningkatkan pertumbuhan dan hasil pada
tanaman.Berdasarkan penelitian Kristina N.N dan Syahid S.T, (2012) dan Prades, A., Dornier, M., Diop, N. \& Pain, J.-P. (2012), kandungan hara yang ada dalam air kelapa(mg/100ml)adalah:N(43mg/ml), $\mathrm{P}$ (30,17 mg/100), K (34,11 mg/100), $\mathrm{Mg}(9,11 \mathrm{mg} / 100 \mathrm{ml}), \mathrm{Fe}(0,25 \mathrm{mg} / 100$ ml) $\mathrm{Na}(21,07 \mathrm{mg} / 100 \mathrm{ml}), \mathrm{Zn}(1,05$ $\mathrm{mg} / 100 \mathrm{ml}), \mathrm{Ca}(24,67 \mathrm{mg} / 100 \mathrm{ml}$.

Hasil penelitian menunjukan bahwa produk hormon dari air kelapa ini mampu meningkatkan hasil kedelai hingga $64 \%$, kacang tanah hingga $15 \%$ dan sayuran hingga 20-30\%. Penelitian lainnya menunjukan bahwa konsentrasi air kelapa $100 \mathrm{ml} /$ tanaman mampu meningkatkan berat basah pada tanaman bawang merah yaitu 4,01 gram (Anonymous, 2007). Hasil penelitian Masniawati (2013), menunjukan bahwa pemanfaatan air kelapa pada daun sawi dengan sistem hidroponik dan dengan konsentrasi $10 \mathrm{ml} / 1$ liter air (1\%) mampu meningkatkan tinggi tanaman mencapai $33,18 \mathrm{~cm}$, jumlah daun (helai) 12,08, panjang $23,59 \mathrm{~cm}$ dan berat basahnya 19,04 gram.

Menurut Muntashilah ,U.H, Islami, T. dan Sebayang, H.T. (2014), kebutuhan nitrogen untuk tanaman kangkung adalah $69 \mathrm{~kg} \mathrm{~N} / \mathrm{ha}, 54 \mathrm{~kg}$ P2O5/ha, dan $21 \mathrm{~kg} \mathrm{K2O/ha.} \mathrm{Dari} \mathrm{data}$ tingkat kebutuhan tanaman kangkung maka dapat diprediksikan kebutuhan air kelapa yang setara dengan kebutuhan tanaman kangkung sebesar 113.37 1t/ha.Asumsi dari kebutuhan unsur hara bagi tanaman kangkung maka dapat diprediksikan kebututuhan air kelapa yang setara dengan kebutuhan tanaman kangkung sebesar 113.37 lt/ha.Adapun 
tujuan penelitian adalah Untuk mengetahui efektivitas pemberian air kelapa dan dosis air kelapa terhadap pertumbuhan dan hasil kangkung darat (ipomoea reptans)".

Berdasarkan hal tersebut diatas, maka ditemukan permaslahan Bagaimana pengaruh pemberian dosis air kelapa terhadap pertumbuhan dan hasil tanaman kangkung darat (ipomoea reptans) dan Berapakah dosis optimum air kelapa yang memberikan pertumbuhan dan hasil tanaman kangkung darat (ipomoea reptans).

Adapun dalam Penelitian ini bertujuan Untuk mengetahui seberapa efektif pemberian air kelapa terhadap pertumbuhan dan hasil kangkung darat (ipomoea reptans)" dan Untuk mengetahui dosis air kelapa yang optimal untuk pertumbuhan dan hasil tanaman kangkung darat (ipomoea reptans).

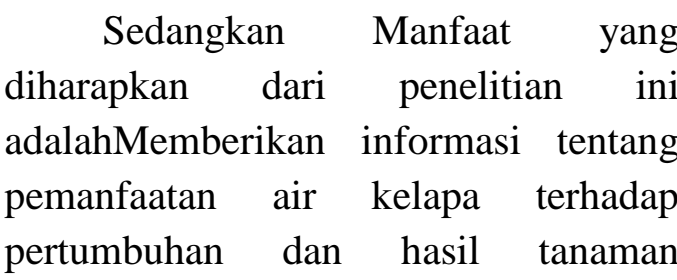
kangkung darat bagi petani, dan Memberikan informasi berapakah dosis optimum air kelapa untuk memberikan pertumbuhan dan hasil tanaman kangkung darat (ipomoea reptans)".

Berdasarkan kerangka berpikir diatas dan hasil penelitian sebelumnya maka dapat diduga bahwa Pemberian air kelapa berpengaruh terhadap pertumbuhan dan hasil tanaman kangkung darat (ipomoea reptans)" dan diduga pula bahwa Pemberian air kelapa dengan dosis 113.37 liter/ha dapat memberikan pertumbuhan dan hasil pada tanaman kangkung darat yang optimal.

\section{METODE PENELITIAN}

Penelitian dilakukan di kebun Percobaan Fakultas Pertanian Universitas Flores, yang berada di Kelurahan Lokoboko, Kecamatan Ndona Kabupaten Ende. Ketinggian tempat 500 meter dpl,curah hujan ratarata $27,45-31,0^{\circ} \mathrm{C}$, kelembapan $70 \%$. Hasil analisis awal kondisi tanah memiliki $\mathrm{pH}$ 5,4 C-organik tergolong rendah dengan nilai $0,15 \%, \mathrm{P}$ tersedia tergolong sedang dengan nilai 19,25 $\mathrm{mg}, \mathrm{K}$ tersedia tergolong tinggi dengan nilai 246,39 $\mathrm{mg} / 100 \mathrm{~g}$ dan memiliki tekstur tanah lempung berpasi (Tage, Edison 2013). Penelitian dilakukan selama 3 bulan

Bahan-bahan yang digunakan dalam percobaan ini adalah: air kelapa tua sebagai perlakuan dalam penelitian, pupuk kandang ayam sebagai pupuk dasar benih kangkung darat, tali rafia, air bersih, sedangkan alat-alat yang digunakan adalah: pacul, parang, saringan, gembor, ember, meteran timbangan, kamera, penggaris dan alat tulis menulis.

Penelitian ini menggunakan rancangan acak kelompok (RAK) yang terdiri dari:

$$
\begin{aligned}
& \mathrm{K}_{0}=\mathrm{Kontrol} \text { (0 liter/ha air kelapa) } \\
& \mathrm{K}_{1}=56,68 \text { liter/ha air kelapa } \\
& \mathrm{K}_{2}=113,37 \text { liter/ha air kelapa } \\
& \mathrm{K}_{3}=170,05 \text { liter/ha air kelapa } \\
& \mathrm{K}_{4}=226,74 \text { liter/ha air kelapa. }
\end{aligned}
$$

Dalam percobaan ini diperoleh 5 perlakuan.Masing-masing perlakuan diulang sebanyak 4 kali sehingga terdapat 20 petak percoabaan. 
Persiapan Lahan dengan cara diolah terlebih dahulu dengan menggunakan cangkul dengan kedalaman 20-30 cm. selanjutnya dilakukan pembentukan bedengan/petak dengan ukuran panjang 1,5 $\mathrm{m}$ dan lebar $1 \mathrm{~m}$, jarak antar perlakuan $50 \mathrm{~cm}$ dan antar ulangan $50 \mathrm{~cm}$ sehingga luas lahan keseluruhan $15 \mathrm{~m}^{2}$. Denah tata letak percobaan di lapangan terlampir.Bersamaan dengan pembentukan bedengan, ditambahkan pupuk kandang sebagai pupuk dasar dengan dosis 20 ton/ha atau $3 \mathrm{~kg} /$ petak, jenis pupuk kandang yang digunakan adalah pupuk kandang ayam NPK dari pupuk kandang N 1.5\% P 1.3\% K 0.8\% (Fauzia 2010).

Penanaman benih kangkung disebar secara merata dalam aluralur/garitan-garitan yang tersedia sebanyak 70-80 benih, jika daya tumbuh $78 \%$ maka terdapat \pm 54 tanaman per larik. Jarak antar tanaman $20 \mathrm{~cm}$ x $25 \mathrm{~cm}$. Penanaman dilakukan pada sore hari..

Air kelapa diberikan denga dosis merata pada petak-petak penelitian selama 3 kali pada umur , 7, 14 dan 21 hst. Interval pemberian air kelapa adalah pada 7 hari dengan dosis yang diberikan; $\mathrm{K}_{1}=(56.68$ liter $/ \mathrm{ha}$ air kelapa $=8,50 \quad$ ml/petak; 2.83 $\mathrm{ml} /$ ptk/aplikasi $) \quad \mathrm{K}_{2}=(113.37$ liter $/ \mathrm{ha}$ air kelapa $=17.01 \mathrm{ml} /$ petak; $=5.66$ $\mathrm{ml} /$ ptk/aplikasi ); $\mathrm{K}_{3}=170.05$ liter/ha air kelapa $=25.51 \mathrm{ml} /$ petak; $=8.50$ $\mathrm{ml} /$ ptk/aplikasi); $\mathrm{K}_{4}=226.74$ liter/petak air kelapa $=34.01 \mathrm{ml} /$ petak. $=11.33$ ml/ptk/aplikasi). Pemberian air kelapa pada tanaman kangkung harus sesuai dengan dosis perlakuan masing-masing, dan di campur dengan air sebanyak 3 liter.

Dalam pelaksanaan penelitian Pemeliharaan yang dilakukan meliputi penyiraman dilakukan pada pagi dan sore hari.Penyiangan dilakukan pada gulma yang tumbuh di sekitar tanaman sehingga tidak terjadi kompetisi atau persaingan terhadap unsur hara, air dan sinar matahari. Penyiangan dilakukan dengan cara mencabut langsung gulma dengan tangan.

Panen dilakukan setelah tanaman kangkung berumur 30 hari setelah tanam, dengan cara mencabut tanaman sampai akarnya atau memotong pada bagian pangkal tanaman sekitar $2 \mathrm{~cm}$ di atas permukaan tanah.

Variabel Penelitian dilakukan Pengamatan terhadap variabel pertumbuhan, variabel komponen hasil.Pengamatan terhadap variabel pertumbuhan dilakukan pada 6 rumpun tanaman sampel.Adapun Variabel Pertumbuhan meliputi :

1. Tinggi Tanaman $(\mathrm{cm})$

Tinggi tanaman diukur mulai dari permukaan tanah sampai daun tertinggi yaitu yang tegak alami. Pengukuran dilakukan pada tanaman sampel pada umur dua minggu setelah tanam dengan interval empat hari yakni 10, 17, 24, hst. 2. Jumlah daun (helai)

Perhitungan jumlah daun dilakukan pada daun yang sudah berkembang sempurna. Pengukuran dilakukan pada tanaman sampel pada umur dua minggu setelah tanam dengan interval empat hari 10, 17, 24, hst.

Sedangkan Variabel hasil meliputi :

1. Berat segar kangkung per petak (gr) 
Berat segar kangkung per petak diperoleh dengan cara menimbang berat segar tanaman sampel pada setiap petak perlakuan. Penimbangan dilakukan pada saat panen yaitu umur $30 \mathrm{hst}$.

2. Berat kangkung per ha $(\mathrm{kg})$.

Pengukuran berat kangkung $\mathrm{ha}^{-1}$ dilakukan dengan cara mengalikan berat segar pertanaman dengan populasi tanaman perhektar (200. 000 tan/ha).

Data hasil pengamatan dianalisis dengan menggunakan analisis sidik ragam sesuai dengan rancangan yang digunakan. Apabila perlakuan menunjukan pengaruh yang nyata atau sangat nyata terhadap variabel yang diamati, maka pengujian dilanjutkan dengan uji nilai beda rata-rata menggunakan uji lanjut BNT 5\%.

\section{HASIL DAN PEMBAHASAN}

Hasil analisis ragam menunjukan bahwa air kelapa memberikan pengaruh yang sangat nyata terhadap variabel pertumbuhan dan hasil kangkung darat pada setiap umur pengamatan. Perlakuan dosis air kelapa berpengaruh sangat nyata terhadap tinggi tanaman jumlah daun pada umur 10, 17, $24 \mathrm{Hst}$, sertaberat segar per petak $(\mathrm{kg})$ dan berat segar per Hektar (ton).

Tabel 1 Signifikansi Pengaruh air kelapa terhadap pertumbuhan dan hasil tanaman kangkung.

Keterangan

\begin{tabular}{clc} 
No & \multicolumn{1}{c}{ Variabel } & Signifikasi \\
\hline 1 & Tinggi Tanaman umur $10 \mathrm{hst}$ & $* *$ \\
2 & Tinggi tanaman umur17 hst & $* *$ \\
3 & Tinggi tanaman umur24 hst & $* *$ \\
4 & Jumlah daun umur $10 \mathrm{hst}_{* *}$ & $* *$ \\
5 & jumlah daun umur $17 \mathrm{hst}$ & $* *$ \\
6 & jumlah daun umur $24 \mathrm{hst}^{1}$ & $* *$ \\
7 & Berat segar kangkung tan- $^{-}(\mathrm{kg})$ & $* *$ \\
\hline
\end{tabular}

Hst : Hari setelah Tanam

** : Sangat Nyata

Hal tersebut diduga karena berbagai komponen atau unsur yang terdapat pada air kelapa.Menurut Untari (2006), air kelapa mengandung sedikit karbonhidrat, protein, lemak dan beberapa mineral. Kandungan zat gizi ini tergantung kepada umur buah.Disamping zat gizi tersebut, air kelapa juga mengandung berbagai asam amino bebas.setiap butir kelapa mengandung air kelapa masing-masing sebanyak $300 \mathrm{ml}$ dengan berat jenis rata-rata 1,02 dan $\mathrm{pH}$ agak asam 5,6. Air kelapa mengandung komposisi kimia dan nutrisi yang lengkap yakni hormon,unsur hara makro dan unsur hara mikro sehingga apabila diaplikasikan pada tanaman akan berpengaruh positif pada tanaman. Air kelapa merupakan endosperm cair yang 
mengandung difenil urea sehigga dapat memacuh pembelahan sel (Armawi 2009). Berdasarkan data analisis Kristina dan Syahid (2012), kandungan hara yang terdapat dalam air kelapa $(\mathrm{mg} / 100 \mathrm{ml})$ adalah sebagai berikut: $\mathrm{N}$ (43 mg/100 ml), P (30,17 mg/100 ml), $\mathrm{K}(34,11 \mathrm{mg} / 100 \mathrm{ml}), \mathrm{Mg}(9,11 \mathrm{mg} / 100$ $\mathrm{ml}), \mathrm{Fe}(0,25 \mathrm{mg} / 100 \mathrm{ml}), \mathrm{Na}(21,07$ $\mathrm{Mg} / 100 \mathrm{ml}), \mathrm{Zn}(1,05 \mathrm{mg} / 100 \mathrm{ml}, \mathrm{Ca}$ ( $24,67 \mathrm{mg} / 100 \mathrm{ml})$.

Menurut Dewi (2008) air kelapa memiliki manfaat untuk meningkatkan pertumbuhan dan hasil pada tanaman. Hasil penelitian menunjukan bahwa air kelapa mengandung kalium hingga 17\%. Selain kalium air kelapa juga mengandung gula antara 1,7 sampai $2,6 \%$ dan protein 0,07 hingga $0,55 \%$. Mineral lainnya antara lain natrium (Na) dan sulfur (S). Disamping kaya mineral, air kelapa juga mengandung berbagai macam vitamin seperti asam sitrat, asam nikotinat, asam pantotenal asam folat niacin, riboflavin dan thiamin.Terdapat pula 2 hormon alami yaitu auksin dan sitokinin sebagai pendukung pembelahan sel embrio kelapa.Air kelapa dapat dibuat suatu produk suplemen yang disebut cocogro. Produk hormon dari air kelapa ini mampu meningkat hasil kedelai hingga $64 \%$, kacang tanah hingga $15 \%$ dan sayuran hingga 20-30 \%. Menurut Yusnida (2006), air kelapa adalah salah satu bahan alami, didalamnya terkandung hormon seperti sitokinin 5,8 $\mathrm{mg} / 1$ dan giberelin serta senyawa lain yaang dapat menstimulasi perkecambahan dan pertumbuhan.

Hasil penelitian Azwar (2008) menyatakan bahwa pemberian $250 \mathrm{ml} / 1$ air kelapa menunjukan waktu yang paling cepat dalam perkecambaahan biji anggrek macan (Grammatohyllum scriptum). Pemberian air kelapa pada konsetrasi rendah $100 \mathrm{ml} / 1$ dapat memberikan pengaruh terbaik terhadap pertumbuhan jamur tiram putih (pleurotus ostratus).Pertumbuhan yang baik akibat pemberian air kelapa diduga karena kandungan auxin sangat berperan terhadap pertumbuhan tersebut.Auksin diproduksi dalam jaringan meristematik yang aktif (yaitu tunas, daun mudaa dan buah).Kelapa muda merupakan salah satu jaringan meristem, sehigga hormon perangsang tumbuhan yang diproduksi didalamnya sangat besar sekali.Hormon diperlukan dalam konsentrasi yang rendah untuk mempengaruhi pertumbuhan tanaman.Auksin adalah zat kimia yang meningkat perpanjangan kleoptil.Walaupun demikian, auksin pada kenyataan mempunyai fungsi ganda pada monocotyledoneae maupun pada dicotyledoneae. Auksin alami yang berada pada tumbuhan adalah asam idol asetat (IAA=Indol Asetat Acid) akan tetapi beberapa senyawa lainnya termasuk beberapa sintetisnya mempunyai aktifitas seperti auksin. Nama auksin digunakan khusus terhadap IAA.Walaupun auksin merupakan tumbuhan pertama yang ditemukan, namun masih banyak yang harus dipelajari tentang transduksi sinyal auksin dan tentang regulasi biosintesis auksin.Kenyataan sekarang mengemukakan bahwa auksin diproduksi dari asam amino tritopan di dalam ujung tajuk tumbuhan (Dewi, 2008). 
Menurut Armawi, (2009), pengaruh menghambat ini kemungkinan terjadi karena konsentrasi IAA yang tinggi mengakibatkan tanaman mensintesis ZPT lain yaitu etilen yang memberikan pengaruh berlawanan dengan IAA. Berbeda dengan pertumbuhan batang, pada akar, konsentrasi IAA yang rendah memacu pemanjangan sel-sel akar sedangkan konsentrasi IAA tinggi menghambat pemanjangan sel akar. Auksin merupakan salah satu hormon yang tumbuh yang tidak terlepas dari proses pertumbuhan dan perkembangan suatu tanaman. Beberapa fungsi auksin pada tumbuhan sebagai berikut: Auksin akan menaikkan kuantitas hasil panen, auksin memacu proses terbentuknya akar serta pertumbuhan akar dengan lebih baik, auksin akan merangsang dan mempertinggi porsentase timbulnya badan buah.

Giberelin mempunyai peranan penting dalam mendukung perpanjangan sel (cel elongtion), aktifitas kambium dan mendukung pembentukan RNA baru serta sintesa protein. Salah satu manfaat dari giberelin yaitu mempercepat pertumbuhan sayur-sayuran serta dapat mempersingkat waktu panen sampai 50 $\%$. Sayur- sayuran biasanya baru dapat dipetik setelah 4 sampai 5 minggu maka dengan penggunaan giberelin, sayur- sayuran tersebut dapat dipetik sehabis 2 atau 3 minggu (Azwar, 2008).

Sitokinin adalah salah satu zat pengatur tumbuh yang mempunyai peranan dalam proses pembelaan sel (cel division). Sitokinin yang dibutuhkan untuk pembelaan sel juga mengatur dan juga berhubungan luas dengan aktifitasaktifitas kisaran dalam morfogenesis. Akar muda, biji dan buah yang belum masak (endospermnya seperti susu) terutama merupakan sumber yang kaya. Karena sitokinin terbukti tidak translokasikan ke jarngan-jaringan ini, diperkirakan disitulah tempat sintesisnya.

Beberapa macam sitokinin merupakan sitokinin alami (misal :kinetin, zeatin) dan beberapa lainnya merupakan sitokinin sinetik. Sitokinin alami dihasilkan pada jaringan yang tumbuh aktif terutama pada akar, embrio dan buah. Sitokinin yang diproduksi di akar selanjutnaya diangkut oleh xilem menuju sel-sel target pada batang. Peningkatan konsentrasi sitokinin ini akan menyebabkan sistem tunas membentuk cabang dalam jumlah yang lebih banyak.berinteraksi antargonis ini umumnya juga terjadi di antara ZPT tumbuhan lainnya (Dewi, 2008). 
Tabel. 2. Pengaruh Pemberian air kelapa terahadap tinggi tanaman dan jumlah daun tanaman kangkung darat.

\begin{tabular}{|c|c|c|c|c|c|c|c|}
\hline \multirow{2}{*}{ Variabel } & \multirow{2}{*}{ perlakuan } & \multicolumn{6}{|c|}{ Umur pengamatan (hst) } \\
\hline & & \multicolumn{2}{|c|}{10} & \multicolumn{2}{|c|}{17} & \multicolumn{2}{|r|}{24} \\
\hline & $\mathrm{K}_{0}$ & 6,57 & $\mathrm{~b}$ & 19,85 & $\mathrm{e}$ & 20,26 & $\mathrm{~d}$ \\
\hline Tinggi & $\mathrm{K}_{1}$ & 6,87 & $\mathrm{~b}$ & 20,26 & $d$ & 20,99 & $\mathrm{c}$ \\
\hline Tanaman & $\mathrm{K}_{2}$ & 7,27 & $a b$ & 20,99 & $\mathrm{c}$ & 24,04 & $\mathrm{~b}$ \\
\hline (cm) & $\mathrm{K}_{3}$ & 7,66 & $\mathrm{a}$ & 21,86 & $b$ & 24,50 & $\mathrm{~b}$ \\
\hline & $\mathrm{K}_{4}$ & 8,39 & $\mathrm{a}$ & 22,85 & $\mathrm{a}$ & 25,21 & $\mathrm{a}$ \\
\hline
\end{tabular}

\begin{tabular}{|c|c|c|c|c|c|c|c|}
\hline BNT 5\% & & 1.0 & & & & 0.46 & \\
\hline \multirow{2}{*}{ Variabel } & \multirow{2}{*}{ perlakuan } & \multicolumn{6}{|c|}{ Umur pengamatan (hst) } \\
\hline & & \multicolumn{2}{|c|}{10} & \multicolumn{2}{|c|}{17} & 24 & \\
\hline \multirow{5}{*}{$\begin{array}{l}\text { Jumlah } \\
\text { Daun } \\
\text { (helai) }\end{array}$} & $\mathrm{K}_{0}$ & 6,46 & $\mathrm{~b}$ & 12,67 & $\mathrm{e}$ & 18,13 & e \\
\hline & $\mathrm{K}_{1}$ & 6,63 & $\mathrm{~b}$ & 13,17 & d & 19,04 & $\mathrm{c}$ \\
\hline & $\mathrm{K}_{2}$ & 6,96 & $a b$ & 13,63 & c & 20,25 & $a b$ \\
\hline & $\mathrm{K}_{3}$ & 7,08 & $\mathrm{a}$ & 14,13 & b & 21,08 & $\mathrm{a}$ \\
\hline & $\mathrm{K}_{4}$ & 7,13 & $\mathrm{a}$ & 14,88 & $\mathrm{a}$ & 21,54 & $\mathrm{a}$ \\
\hline
\end{tabular}

BNT 5\% 0.39 0.19 1.13

Keterangan: Angka-angka yang diikuti oleh huruf yang sama pada kolomyang sama menunjukan pengaruh yang tidak berbeda nyata pada taraf uji BNT $5 \%$.

Berdasarkan data pada table 2 menunjukan bahwa peningkatan pemberian air kelapa diikuti oleh peningkatan pertumbuhan tanaman kangkung darat. Rataan total pertumbuhan pada tinggi tanaman dan jumlah daun secara berturut-turut dari K0 (tanpa air kelapa) ke K1 (56.68) ltr/ha air kelapa yaitu, $3.29 \%$ dan 3.70 \%. K1 ke K2 (113.37) liter/ha air kelapa yaitu, $3.32 \%$ dan $4.20 \%$. K2 ke K3 (170.05 liter/ha air kelapa yaitu, $3.67 \%$ dan $3.08 \%$. K3 ke K4 (226.74) liter/ha iar kelapa yaitu, $5.27 \%$ dan $4.58 \%$. Peningkatan persentase rataan total tinggi tanaman dan jumlah daun pada variabel pengamatan menunjukan bahwa hipotesis pertama (1) diterima, karena air kelapa dapat memberikan peningkatan pertumbuhan pada tanaman kangkung. Hal ini disebabkan karena adanya unsur hara yang terdapat dalam air kelapa (N, P, K, Fe, Na, Zn, Ca) yang dapat memperbaiki sifat fisik dan biologi tanah ( Kristina dan Syahid,
2012). Peningkatan dosis air kelapa yang diberikan, juga akan meningkatkan jumlah unsur hara yang dapat dimanfaatkan oleh tanaman kangkung. Kebutuhan hara untuk tanaman kangkung darat sendiri adalah $69 \mathrm{~kg} \mathrm{~N} / \mathrm{ha}, 54 \mathrm{~kg} \mathrm{P} 2 \mathrm{O} 5 / \mathrm{ha}$, dan $21 \mathrm{~kg}$ $\mathrm{K} 2 \mathrm{O} /$ ha (Margianto ,2009).

Hasil penelitian menunjukan bahwa pemberian air kelapa dengan dosis tertinggi $\mathrm{K} 4=226.74$ liter $\mathrm{ha}^{-1}$ (34,01 mili liter petak $\left.^{-1}\right)$ memberikan pertumbuhan tinggi tanaman $(25,21 \mathrm{~cm})$ dan jumlah daun(21,54helai) yang paling tinggi dibandingkan perlakuan dosis lainnya dan control (K3: $24,50 \mathrm{~cm}$ dan 21,08 helai, K2 : 24,04 cm dan 20,25 helai, K1 : 20,99cm dan 19,04 helai KO 20,26 cm dan 18,13 helai). Hal ini dapat terjadi karena NPK dalam air kelapa dengan dosis 226,74 liter ha ${ }^{-}$ ${ }^{1}$ terdapat kandungan $\mathrm{N}(4.3 \mathrm{~kg}), \mathrm{P}(3.7$ $\mathrm{kg}), \quad \mathrm{K}(3.1 \mathrm{~kg})$ serta mengandung hormon auksin, stikoinin dan giberelin yangcukup. 


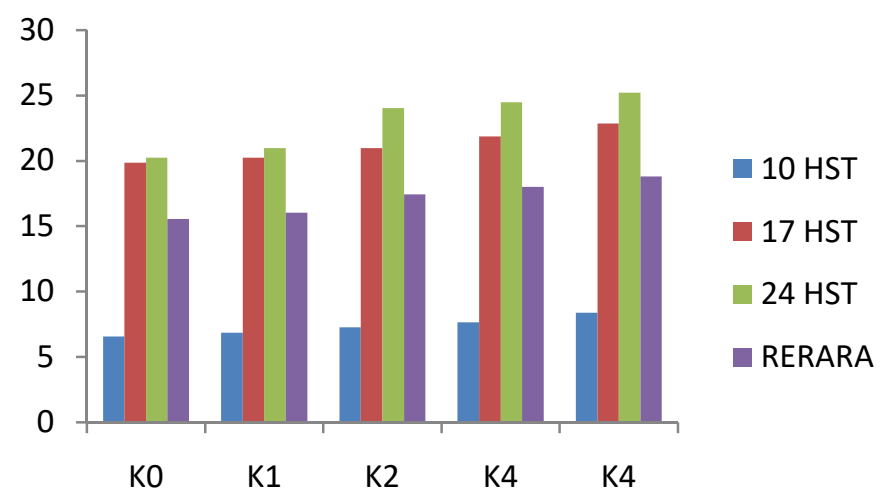

Gambar 1. Hasil Pengamatan Tinggi Tanaman Kangkung akibat Pemberian air Kelapa

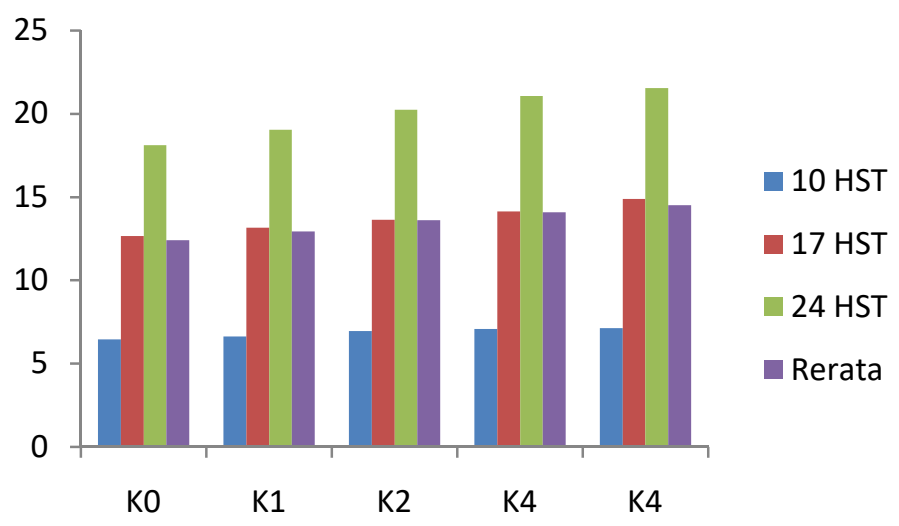

Gambar 2. Hasil Pengamatan Jumlah daun Tanaman Kangkung akibat Pemberian air Kelapa

Menurut Fauzia (2010). Kandungan auksin dan stikoinin yang terdapat dalam air kelapa mempunyai peranan penting dalam proses pembelahan sel sehingga membantu pembentukan tunas dan pemanjangan batang. Auksin akan memacu sel untuk membela secara cepat dan berkembang menjadi tunas dan batang. Ini didukung oleh hasil penelitian Suryanto(2009), yang menyatakan bahwa hormone tumbuh dalam air kelapa mampu menungkatkan pertumbuhan tanaman hinggga $20-70 \%$.

Menurut Azwar (2008), air kelapa ternyata memiliki manfaat untuk meningkatkan pertumbuhan tanaman. Hasil penelitian menunjukan bahwa air kelapa kaya akan potasium (kalium) hingga $17 \%$. Selain kaya mineral, air kelapa juga gula antara 1,7 sampai 2,6 $\%$ dan protein 0,07 hingga $0,55 \%$. Mineral lainnya antara lain natrium $(\mathrm{Na})$, kalsium $(\mathrm{Ca})$, magnesium $(\mathrm{Mg})$, feru $(\mathrm{Fe})$, cuprum $(\mathrm{Cu})$, fosfor $(\mathrm{P})$, dan sulfur $(\mathrm{S})$. disamping kaya mineral, air kelapa juga mengandung berbagai macam vitamin seperti asam sitrat, asam nikotinat, asam pantotenal, asam folat, niacin, riboflavin, dan thiamin. Terdapat pula 2 hormon alami yaitu auksin dan sitokinin sebagai pendukung pembelahan sel embrio kelapa.

Hasil penelitian menunjukan bahwa produk hormon dari air kelapa ini mampu meningkatkan hasil kedelai 
hingga $64 \%$, kacang tanah hingga $15 \%$ dan sayuran hingga 20-30 \%. Penelitian lainnya menunjukan bahwa konsentrasi air kelapa $100 \mathrm{ml} /$ tanaman mampu meningkatkan berat basah pada tanaman bawang merah yaitu 4,01 gram (Anonymous, 2007). Hasil penelitian Masniawati (2013), menunjukan bahwa pemanfaatan air kelapa pada daun sawi dengan sistem hidroponik dan dengan konsentrasi $10 \mathrm{ml} / 1$ liter air (1\%) mampu meningkatkan tinggi tanaman mencapai $33,18 \mathrm{~cm}$, jumlah daun (helai) 12,08 , panjang $23,59 \mathrm{~cm}$ dan berat basahnya 19,04 gram.

Hasil penelitian Hayati (2011), menunjukan konsentrasi air kelapa sebanyak 50\% (500 ml air kelapa : 1 liter air) mampu memberikan peningkatan pada pertumbuhan dan hasil jamur merang yaitu tinggi tanaman $34,54 \mathrm{~cm}$, diameter tubuh buah 3,32, berat total 1585,82 gram, jumlah total tubuh buah 136, dan berat rata-rata 13,76 gram. Menurut Margianto (2009) kebutuhan nitrogen untuk tanaman kangkung adalah $69 \mathrm{~kg} \mathrm{~N} / \mathrm{ha}, 54 \mathrm{~kg}$ P2O5/ha, dan $21 \mathrm{~kg} \mathrm{~K} 2 \mathrm{O} / \mathrm{ha}$.Dari data tingkat kebutuhan tanaman kangkung maka dapat diprediksikan kebutuhan air kelapa yang setara dengan kebutuhan tanaman kangkung sebesar 113.37 lt/ha.

Pernyataan ini juga menunjukan bahwa hipotesis kedua
ditolak.Karena tanaman belum dapat memberikan pertumbuhan tinggi, jumlah daun yang optimal.Hal ini diduga karena factor lingkungan tumbuh disekitar tanaman belum sesuai, diantaranya ketersediaan hara dalam tanah, struktur tanah dan tata udara tanah yang sangat mempengaruhi pertumbuhan dan perkembangan akar serta kemampuan akar tanaman dalam menyerap unsure hara.Pertumbuhan vegetatif tanaman dapat berjalan baik apabila didukung dengan perkembangan sistim perakaran yang baik pula. Selain kebutuhan hara, tanaman kangkung darat menghendaki curah hujan 500$5000 \mathrm{~mm} /$ tahun, suhu udara $27^{0} \mathrm{C}-32^{0} \mathrm{C}$ , kelembaban udara $80 \%$ - 90\%, jenis tanah yang sesuai adalah lempung berpasir seperti andosol,pH antara 6-7, ketinggian tempat 100-500 meter dpl. Dibandingkan dengan kondisi tempat penelitian yang memiliki tanah yang kurang subur dengan $\mathrm{pH} 5,4$, C_Organik tergolong rendah dengan nilai $1,42 \% \mathrm{~N}$ total tergolong rendah dengan nilai $0,15 \%$ dan jenis tanah lempung berpasir (Tage, Edison 2013). Melihat data tersebut diatas dapat diketahui bahwa kondisi $\mathrm{pH}$ tanah, Corganic dan $\mathrm{N}$ total yang rendah dapat menyebabkan pertumbuhan tanaman kangkung menjadi tidak optimal.

Table3 .Pengaruh pemberian Air kelapa terhadap Variabel hasil tanaman kangkung darat

\begin{tabular}{ccccc}
\hline \multirow{2}{*}{ Perlakuan } & \multicolumn{4}{c}{ Variabel Hasil } \\
\cline { 2 - 5 } & \multicolumn{3}{c}{ Berat Segar } & \multicolumn{2}{c}{ Berat } \\
& Kangkung per petak(kg) & Kangkung ha- ${ }^{1}$ (ton) \\
\hline K0 & 6,83 & E & 45,5 & D \\
K1 & 9,38 & D & 62,5 & C \\
K2 & 10,13 & C & 67,5 & C \\
K3 & 13,58 & B & 90,5 & B \\
K4 & 18,23 & A & 121,5 & A \\
\hline BNT 5\% & $\mathbf{3 , 2 8}$ & $\mathbf{6 , 7 3}$ \\
\hline
\end{tabular}

Keterangan: Angka-angka yang diikuti oleh huruf yang sama pada kolom yang sama menunjukan pengaruh yang tidak berbeda nyata pada taraf uji BNT $5 \%$. 
Hasil analisis sigik ragam menunjukan bahwa pemberian dosis air kelapa yang berbeda memberikan pengaruh yang sangat nyata terhadap variabel hasil tanaman kangkung- ${ }^{1}$ dan hasil kangkung ha- ${ }^{1}$ rataan total dari masing-masing perlakuan secara berturut-turut dari K0 tanpa air kelapa ke k1 56,68 liter/ha air kelapa yaitu, $0,27 \%$ dan $0,27 \%$. K1 ke K2 $(113,37)$ liter/ha air kelapa yaitu, $0,07 \%$ dan 0,07\%. K2 ke K3 (170.05 liter/ha air kelapa yaitu, $0,25 \%$ dan $0,25 \%$. K3 ke K4 $(226,74)$ liter/ha iar kelapa yaitu, $0.25 \%$ dan $0,25 \%$. Peningkatan persentase pada variabel hasil membuktikan bahwa peningkatan dosis air kelapa dapat meningkatkan hasil pada tanaman kangkung sesuai dengan hipotesis pertama (1). Hal ini disebabkan semakin tinggi dosis yang di beri maka unsur hara yang tersedia bagi tanaman juga akan semakin banyak, sehingga kesempatan untuk tanaman dapat menyerap unsur hara tersebut semakin baik. Pemberian air kelapa yang dapat meningkatkan tinggi, jumlah daun kangkung juga sangat mempengaruhi berat segar kangkung tanaman per petak dan produksi kangkung per hektar. Peningkatan tersebut terjadi disebabkan tanaman memiliki tinggi, dan jumlah daun yang baik yang dapat membentuk dan menyimpan zat hara lebih banyak sehingga tunas tanaman baru lebih cepat dengan daya tumbuh yang optimal. Semakin tinggi dan semakin banyak jumlah tanaman akan menambah berat dari tanaman tersebut (Ratna 2002).

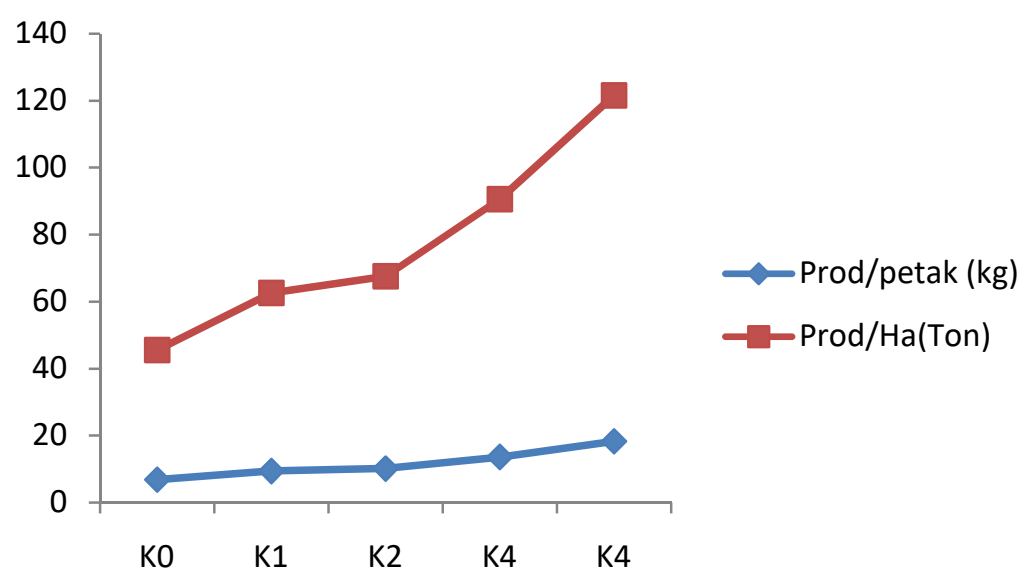

Dari hasil penelitian juga menunujukan bahwa pemberian air kelapa pada dosis $\mathrm{K}_{2}$ : 113, 37 liter/ha air kelapa tidak terbukti terhadap hasil kangkung sehingga hipotesis (2) ditolak karena tidak keseimbangan kebutuhan unsur hara yang diberikan pada tanaman membuat tanaman tidak dapat tumbuh berkembang dan memberikan hasil produksi yang tidak optimal. Sedangkan perlaku yang terbaik adalah $\mathrm{K}_{4}$ : 226,74 liter/ha yang setara dari
NPK air kelapa dengan dosis $\mathrm{N}$ (4.3kg), P (3.7 kg), K (3.1 kg) Fauzia, (2010) dimana dosis masih kurang dibandingkan dengan kebutuhan hara yang dibutuhkan oleh tanaman kangkung darat. Dari hasil penelitian membuktikan bahwa $\mathrm{K}_{4}$ sangat berbeda nyata dengan perlakuan lainnya yaitu $\mathrm{K}_{3}, \mathrm{~K}_{2}, \mathrm{~K}_{1}$ dan $\mathrm{K}_{0}$.

Jika dilihat dari sudut pandang kelompok tanaman ini dapat tumbuh dengan baik sepanjang tahun.Kangkung 
darat dapat tumbuh pada daerah yang beriklim panas dan beriklim dingin. Selain kebutuhan hara tanaman kangkung juga membutuhkan curah hujan 100-1500 mm/tahun, ketinggian 500 meter dpl, kelembapan $70 \%$. Hasil analisis awal kondisi tanah memiliki $\mathrm{pH}$ 5,4 C-organik tergolong rendah dengan nilai $0,15 \%, \mathrm{P}$ tersedia tergolong sedang dengan nilai $19,25 \mathrm{mg}, \mathrm{K}$ tersedia tergolong tinggi dengan nilai 246,39 $\mathrm{mg} / 100 \mathrm{~g}$ dan memiliki tekstur tanah lempung berpasir (Tage, Edison 2013).

Sedangkan Kangkung darat (Ipomea reptans) menghendaki tanah yang subur, gembur banyak mengandung bahan organik dan tidak dipengaruhi keasaman tanah. Tanaman kangkung darat tidak menghendaki tanah yang tergenang, karena akar akan mudah membusuk. Sedangkan kangkung air membutuhkan tanah yang selalu tergenang air.Tanaman kangkung darat (Ipomea reptans) membutuhkan tanah datar bagi pertumbuhannya, sebab tanah yang memiliki kelerengan tinggi tidak dapat mempertahankan kandungan air secara baik (Haryoto, 2009). Oleh sebab itu hal ini akan mempengaruhi produktivitas tanaman kangkung.

\section{SIMPULAN}

Pemberian air kelapa berpengaruh sangat nyata terhadap porsentase rataan tinggi tanaman 5,27\%, jumlah daun $4,58 \%$, berat segar kangkung tan${ }^{1} 0,26 \%$ dan berat kangkung ha- ${ }^{1} 0,26 \%$. dandosis optimum air kelapa 226.74 liter/ha (K4) dapatmemberikan pertumbuhan tinggi tanaman $25.21 \mathrm{~cm}$, jumlah daun 21.54 helai, berat segar kangkung darat tan- ${ }^{1} 18,23 \mathrm{~kg}$, berat kangkung darat ha- ${ }^{1} 121,5$ ton. Karena itu budidaya kangkung darat dapat mengaplikasikanair kelapa dengan dosis 226.74 liter/ha, karena dapat meningkatkan pertumbuhan dan hasil tanaman kangkung darat.

\section{UCAPAN TERIMA KASIH}

Ucapan terimakasih kami sampaikan kepada beberapa pihak yang mendukung penelitian iniantara lain yaitu :Dekan Fakultas Pertanian, Wakil Dekan, Ketua Program Studi dan segenap jajarannya, Dosen-dosen yang sudah memberikan kritik dan saran untuk kesempurnaan tulisan ini, serta seluruh ttim yang sudah terlibat dan membantu penelitian ini.

\section{DAFTARPUSTAKA}

Anonymous. 2007. ( PengaruhAir kelapa Terhadap Pertumbuhan dan Hasil Bawang Merah. Http.//Wikipedia.org/airkelapa. Diakses tanggal 28 maret 2015

Bey, Y., Wan Syafil, Sutrisna, 2006.Pengaruh Pemberian Giberelin dan Air Kelapa terhadap Pertumbuhan Anggek Bulan. J. Biogenesis. 2(2): 41-46

Harjadi \& Suketi, 1999.Produksi kangkung di Indonesia dapat mencapai 50.000-60.000 kg per hektar.Bandung ITB

Kristina, N.N. \& Syahid, S.T. (2012) Pengaruh Air Kelapa Muda terhadap Multiplikasi Tunas In Vitro, Produksi Rimpang, dan Kandungan Xanthorrhizol Temulawak di Lapangan. Jurnal Littri. 18 (3), 125134

Masniawati. 2013. Optimalisasi pertumbuhan dan produksi tanaman sawi hijau (Brassica Juncea L) secara HYidroponik dengan Pemberian Berbagai Bahan Organik Cair. Jurusan Biologi FMIPA Fakultas Pertanian Universitas Hasanudin.

Muntashilah ,U.H, Islami, T. dan Sebayang, H.T.,. 2014.Pengaruh Dosis Pupuk Kandang Sapi Dan Pupuk Nitrogen Terhadap Pertumbuhan Dan Hasil Tanaman Kangkung Darat(Ipomoea Reptans.Poir).Skripsi. Universitas Brawijaya. Malang 
Santoso, B.B. 2013.Zat Pengatur Tumbuh Dalam Pertumbuhan dan Perkembangan tanaman. Universitas Sam Ratulangi. Menado

Sawasemariai, 2012.Kangkung darat menempati urutan ke-14 dari 18 jenis sayur di Indonesia .Pengkajian dan Pengembangan Pertanian jakarta.

Seswita, D. (2010) Penggunaan Air Kelapa sebagai Zat Pengatur Tumbuh pada Multiplikasi Tunas Temulawak (Curcuma xanthorrhiza Roxb.). Jurnal Littri. 16 (4), 135140.

Setiawan .P. 2013. Pengaruh Perendaman Benih Kakao dalam air Kelapa dan Pemberian Pupuk NPKMg (15-15-6-4) Terhadap Pertumbuhan Bibit Kakao
(Theobroma cacao L ). J. Online Agroteknologi. 1(4) 37-40.

Tage.,D.E. 2013. Pengaruh Pemberian Mulsa Jerami Padi Terhadap Pertumbuhan dan hasil Tanaman cabai Besar (Capsicum Annum L).fakultas Pertanian.Universitas Flores.Ende.

Prades, A., Dornier, M., Diop, N. \& Pain, J.-P. (2012) Coconut Water Uses, Composition and Properties: A Review. Fruits. 67 (2), 87-107. doi:10.1051/ fruits/2012002.

Wulandari, R.C., Riza Linda dan Mukarlina. 2013. Pertumbuhan Stek Melati Putih (Jasminum sambac L) dan Pemberian Air Kelapa dan IBA ( Indole Butryc Acid ) J. Protobiont. 2(2): 